\title{
Analisis Wacana Kritis terhadap Iklan-Iklan Pajak dalam Pembentukan Realitas pada Kehidupan Masyarakat
}

\author{
Critical Discourse Analysis on Tax Advertisements in Forming Reality \\ to the Society Life
}

Agung Suryo Nugroho

Linguistik UI

\begin{abstract}
Abstrak
Iklan pajak umumnya merupakan iklan yang bertujuan untuk menghimbau dan mengajak masyarakat untuk membayar pajak. Berbagai pesan yang ingin disampaikan oleh pembuat teks iklan mendapatkan pengaruh yang signifikan dari institusi yang memesannya, yaitu institusi pajak. Disadari atau tidak, realitas tertentu dibentuk atau terbentuk melalui teks tersebut, namun realitas seperti apa yang dibentuk atau terbentuk melalui iklan ini dan apa implikasinya terhadap khalayak umum? Penelitian pada makalah ini akan mengkaji tiga iklan pajak yang pernah ditayangkan di media TV. Iklan ini dianalisis menggunakan Analisis Wacana Kritis (AWK) yang ditawarkan oleh Norman Fairclough. Fairclough (1995: 23) membagi AWK dalam tiga dimensi yang saling berhubungan; text, discourse practice dan sociocultural practice. Berdasarkan hasil penelitian, dapat ditarik kesimpulan bahwa pada ketiga dimensi tersebut, teks iklan ini didominasi untuk tujuan pencitraan. Selain itu, teks ini juga dibuat dengan mengangkat realitas yang ada serta membentuk realitas tertentu di dalam masyarakat.
\end{abstract}

Kata kunci: Iklan pajak, Analisis Wacana Kritis, Realitas.

\begin{abstract}
Tax advertisement is generally an advertisement that has purpose to urge and persuade people in paying tax. There are some messages created by advertising agent which significantly influenced by the institution who order it. Conciously or not, certain reality is formed through the text, however, what kind of reality that is formed by this advertisement and what is the implication to the society? This paper will analyze three tax advertisements which ever showed in TV. These advertisements will be analyzed by using Critical Discourse Analysis (CDA) theory created by Norman Fairclough. Fairclough (1995: 23) divides CDA into three related dimensions; text, discourse practice dan sociocultural practice. According to these dimensions, these text advertisements is dominated for positive self-representation. Beside that, these texts is created by viewing actual reality and form certain reality in the society.
\end{abstract}

Keywords: Tax advertisement, Critical Discourse Analysis (CDA), Reality 


\section{PENDAHUluAN}

Kajian Wacana pada umumnya digunakan untukmenganalisis suatu teks untukmemahami pesan yang terkandung. Renkema (2004: 1) mendefinisikan Kajian Wacana sebagai disiplin ilmu yang mempelajari hubungan antara bentuk dan fungsi dalam bentuk komunikasi verbal (baik lisan maupun tulisan). Tujuan dari Kajian Wacana adalah memberikan penjelasan dari hubungan yang berbelit- belit antara unsur-unsur wacana dan fungsinya dalam komunikasi. Analisis wacana dipandang kritis atau dikenal dengan analisis wacana kritis (AWK) karena menekankan konstelasi kekuatan yang terjadi pada proses produksi dan reproduksi makna. Individu dipandang tidak sebagai subjek yang netral yang menafsirkan secara bebas sesuai dengan pikirannya karena sangat dipengaruhi dan berhubungan oleh kekuatan sosial yang ada dalam masyarakat (Eriyanto,

2001: 6). Fairclough (1995: 23) memandang AWK sebagai penyatuan analisis teks, analisis proses produksi, distribusi dan konsumsi teks serta analisis sosiokultural dari praktik diskursif.

Menurut Fairclough dalam Eriyanto (2001: 289), teks pada dasarnya dapat diuraikan dan dianalisis dari tiga unsur, yaitu; representasi, relasi dan identitas. ${ }^{1}$ Representasi pada dasarnya ingin melihat bagaimana seseorang, kelompok, tindakan dan kegiatan ditampilkan dalam teks. Representasi dalam pengertian Fairclough dilihat dari dua hal, yakni bagaimana seseorang, kelompok dan gagasan ditampilkan dalam anak kalimat, dan gabungan atau ringkasan antaranak kalimat. Relasi berhubungan dengan bagaimana partisipan dalam media berhubungan dan ditampilkan dalam teks. Sementara itu, dalam analisis

identitas, dilihat bagaimana identitas wartawan (sebagai pembuat teks) ditampilkan dan dikonstruksi dalam teks pemberitaan. Identitas tersebut dilihat melalui bagaimana wartawan mengidentifikasikan dirinya dalam pemberitaan, apakah ia berpihak pada salah satu partisipan ataukah ia menempatkan dirinya sebagai pihak yang bebas.

Pada bagian praktik wacana, analisis dipusatkan pada bagaimana produksi

1 Uraian mengenai elemen teks ini didasarkan dan disarikan dari tulisan Fairclough berikut: Norman Fairclough, Media Discourse, London, Edward Arnold, 1995, terutama hlm. 103149; Norman Fairclough, "Discourse and Text: Linguistic and Intertextual Analysis within Discourse Analysis", dalam Critical Discourse Analysis, London and New York, Longman, 1998, hlm. 187- 214; Norman Fairclough, Discourse and Social Change, Cambridge, Polity Press, 1992, hlm. 169-199.

dan konsumsi teks. Menurut Fairclough, ada dua sisi dari praktik diskursus; produksi teks (di pihak media) dan konsumsi teks (di pihak khalayak). Kedua hal tersebut berhubungan dengan jaringan yang kompleks yang melibatkan berbagai praktik diskursif.

Pada bagian praktik sosial-budaya, analisis didasarkan pada asumsi bahwa konteks sosial yang ada di luar media mempengaruhi bagaimana wacana yang muncul dalam media. Praktik ini memang tidak berhubungan lengsung dengan produksi teks, namun menentukan bagaimana teks diproduksi dan dipahami. Praktik ini menggambarkan bagaimana kekuatankekuatan yang ada dalam masyarakat memaknai dan menyebarkan ideologi yang dominan kepada masyarakat.

Makalah ini akan menganalisis secara kritis iklan-iklan pajak yang muncul di media TV. Iklan pajak umumnya merupakan iklan yang bertujuan untuk menghimbau dan mengajak masyarakat untuk membayar pajak. Berbagai pesan yang ingin disampaikan oleh pembuat teks iklan mendapatkan pengaruh yang signifikan dari institusi yang memesannya, yaitu institusi pajak. Disadari atau tidak, realitas tertentu dibentuk atau terbentuk melalui teks 
tersebut, namun realitas seperti apa yang dibentuk atau terbentuk melalui iklan ini dan apa implikasinya terhadap khalayak umum?

Penelitian-penelitian sebelumnya yang menggunakan AWK Fairclough telah banyak dilakukan namun tidak terpusat di satu bidang bahasan tertentu. Rogers (2005) telah mengkaji AWK dalam dunia pendidikan. Scheuer (2003) menggunakan AWK untuk menganalisis kegiatan wawancara. Blommaert \& Bulcaen (2000) mensurvei mengenai AWK yang berhubungan dengan kekuasaan dan ketidakadilan dalam bahasa. Phillips, Lawrence \& Hardy (2004) mengkaji hubungan antara teks, wacana, institusi dan tindakan, serta mengembangkan model diskursif dari pelembagaan yang menyoroti hubungan antara wacana dan tindakan sosial melalui produksi dan konsumsi teks. Powell (2004) mencoba menggunakan AWK untuk menganalisis teks yang beredar di Universitas Miami, Ohio, dan bagaimana AWK memberikan informasi mengenai komposisi pengajaran.

Penelitian-penelitian di dalam negeri yang menggunakan AWK Fairclough banyak bermunculan, namun umumnya digunakan untuk menganalisis teks pada media massa seperti koran. Hal ini wajar karena teori Fairclough memang pada dasarnya digunakan untuk menganalisis jenis teks tersebut untuk melihat keberpihakan wartawan (pembuat teks). Penulis mencoba menggunakan teori Fairclough tersebut untuk menganalisis teks iklan, terutama iklan non-komersial yang jelas berpihak kepada pemerintah untuk melihat bagaimana pembuat teks (biro iklan) merangkai kata sedemikian rupa untuk menarik rasa simpati dan empati khalayak dalam membayar pajak serta mengangkat dan membentuk realitas tertentu. Penelitian terhadap iklan dengan menggunakan pendekatan Analisis Wacana Kritis belum penulis temukan sehingga hal ini menarik untuk disimak.

\section{METODOLOGI}

Jenis penelitian ini adalah kualitatif. Untuk menganalisis korpus data dalam penelitian ini, penulis menggunakan AWK yang ditawarkan oleh Fairclough. Fairclough berupaya membangun suatu model analisis wacana yang mempunyai kontribusi dalam analisis sosial dan budaya, sehingga ia mengkombinasikan tradisi analisis tekstual - yang selalu melihat bahasa dalam ruang tertutup - dengan konteks masyarakat yang lebih luas. Titik besar perhatiannya adalah melihat bahasa sebagai praktik kekuasaan. Oleh karena itu, analisis harus dipusatkan pada bagaimana bahasa itu terbentuk dan dibentuk dari relasi sosial dan konteks tertentu.

Fairclough membagi analisis wacana dalam tiga dimensi; text, discourse practice dan sociocultural practice. Penelitian ini menggunakan tiga iklan pajak sebagai korpus data yang diunduh dari situs www.youtube.com pada bulan Juli 2012. Data ini dipilih karena iklan-iklan pajak ini berasal dari institusi pemerintah yang dianggap memiliki kuasa untuk meminta masyarakatnya agar taat membayar pajak. Iklan ini memiliki karakteristik yang unik karena pembuat teks merangkai kalimat sedemikian rupa untuk menarik simpati dan empati masyarakat agar membayar pajak dan mencoba mengangkat \& membentuk realitas tertentu.

\section{HASIL DAN PEMBAHASAN}

Setelah memaparkan metode, teori dan jenis data yang digunakan dalam makalah ini, penulis akan menganalisis data yang telah tersedia dengan menggunakan teori yang telah dikemukakan di bagian sebelumnya. Data teks iklan-iklan pajak akan dianalisis menggunakan teori AWK Fairclough dalam tiga dimensi, yaitu dimensi teks, praktik wacana dan praktik sosial-budaya. 


\section{Analisis pada Dimensi Teks}

Representasi pada dasarnya ingin melihat bagaimana seseorang, kelompok, tindakan dan kegiatan ditampilkan dalam teks. Representasi ditampilkan dalam anak kalimat, dan gabungan atau ringkasan antaranak kalimat. Berikut ini adalah analisis ketiga teks iklan pajak tersebut:

\section{Analisis Representasi dalam Anak Kalimat}

Dalam analisis representasi di tingkat anak kalimat, analisis akan ditujukan terhadap kosakata dan tata bahasa yang dapat menunjukkan pandangan pembuat teks iklan yang melatarbelakanginya. Pada bagian ini, analisis berfokus pada bagaimana pembuat teks merepresentasikan seseorang, kelompok, tindakan, atau peristiwa melalui kosakata dan tata bahasa. Dengan menganalisis bagian ini, ideologi dari pembuat wacana dapat terlihat.

\section{Iklan I}

(1) Siapa yang tidak bahagia, melihat jutaan anak Indonesia dapat terus sekolah...

Dalam anak kalimat di atas, terdapat pemakaian metafora. Frasa metaforis tersebut yaitu anak Indonesia yang digunakan untuk merujuk kepada anak yang lahir di negara Indonesia yang masih dalam tanggungan orang tuanya. Penggunaan metafora tersebut dapat ditafsirkan bermacam-macam oleh penulis. Penggunaan frasa tersebut dimaknai sebagai sesuatu yang positif yang dapat membangkitkan jiwa nasionalisme. Frasa tersebut memiliki fungsi strategis dalam menarik simpati masyarakat untuk membayar pajak. Frasa tersebut dapat saja digantikan dengan frasa anak yang kurang mampu, anak miskin atau anak yang kurang beruntung karena merekalah sebenarnya yang menjadi sasaran utama dalam pembiayaan pajak ini. Namun di sini terdapat kesulitan dalam mendefinisikan miskin atau kurang mampu tersebut karena frasa-frasa tersebut bersifat relatif. Batasan antara kaya dan miskin sangat relatif, yang sangat bergantung pada situasi, kondisi dan sikap manusianya.

Penggunaan frasa tersebut dianggap dapat menghilangkan kesenjangan antara anak yang kaya dan miskin. Sebagaimana diketahui, sasaran dari program pajak tersebut adalah semua siswa dari jenjang Sekolah Dasar (SD) hingga Sekolah Menengah Pertama (SMP), bahkan mulai merambah ke tingkat SMA/SMK yang mana tidak semua siswa pada jenjang tersebut adalah siswa yang kurang mampu. Terdapat juga siswa yang berasal dari keluarga yang mampu atau sangat mampu yang juga menerima bantuan tersebut. Program tersebut memang tidak sepenuhnya tepat sasaran, namun manfaatnya dapat dirasakan bagi mereka yang berasal dari keluarga tidak mampu.

(2) Siapa yang tidak bahagia, melihat jutaan anak Indonesia dapat terus sekolah

... Siapa yang tidak terharu melihat makin banyak keluarga bisa memperoleh berbagai layanan kesehatan dan obat-obatan tanpa harus memikirkan besarnya biaya ... Siapa yang tidak tersentuh melihat makin banyak ibu yang melahirkan selamat, bayi lahir sehat dan tumbuh cerdas tanpa harus merisaukan beratnya biaya ...

Pada bagian tata bahasa dalam teks iklan ini, bentuk mental sangat ditonjolkan oleh pembuat teks. Dari beberapa kalimat di atas, pembuat teks ingin membentuk kesadaran khalayak bahwa fungsi pajak sangat penting. Pembuat teks tidak mengungkapkan subjek yang menjadi penekanan secara spesifik dengan hanya menggunakan kata tanya siapa, namun dengan itu, ia mencoba menarik simpati dan empati masyarakat. Diharapkan dengan tergugahnya simpati dan empati masyarakat tersebut, mereka akan menyisihkan pendapatannya untuk membayar pajak. Teks iklan ini ingin membentuk realitas bahwa jika orang taat membayar pajak, maka sektor pendidikan dan kesehatan dapat memberikan 
pelayanan prima kepada masyarakat sebagai timbal balik dari pajak itu sendiri. Namun realitas yang ada, masih banyak masyarakat kurang mampu sulit untuk mendapatkan pelayanan kesehatan yang maksimal seperti yang diiklankan.

\section{Iklan II}

Iklan yang akan dianalisis ini berbeda fungsinya dari iklan pajak lainnya yang sudah pernah ditayangkan di media elektornik. Iklan ini tidak sepenuhnya menjabarkan manfaat dari pajak, namun mencoba menggambarkan beratnya tanggung jawab dan kepercayaan seorang pegawai pajak dalam melakukan tugasnya. Walaupun demikian, ia tetap merasa bangga dan bersyukur karena mengemban tugas tersebut.

\section{(3) Betapa aku bangga dan bersyukur dapat mengemban tugas mulia ini ...}

Dalam analisis ini, penulis akan memfokuskan analisis pada frasa tugas mulia yang terdapat di awal teks iklan. Frasa ini mengacu kepada tugas-tugas seorang pegawai pajak. Pembuat teks menggunakan frasa tersebut untuk diasosiasikan dengan tugas yang dapat memberikan sumbangsih yang besar untuk kesejahteraan bangsa. Pembuat teks menyandingkan kata tugas dengan kata mulia untuk memberikan citra positif terhadap tugas-tugas pegawai pajak.

Pencitraan tersebut dilakukan pada saat banyak tindak korupsi yang terjadi di sektor pajak. Kata tugas bisa saja disandingkan dengan kata negara sehingga menjadi tugas negara, karena pegawai tersebut menjalankan tugasnya untuk negara seperti halnya TNI yang mengabdikan jiwa dan raganya untuk membela negara dari segala bentuk ancaman. Kata mulia dipilih mungkin dikarenakan selain pencitraan positif untuk pajak, juga dapat dikarenakan untuk menarik simpati masyarakat dan secara tidak langsung meminta kepercayaan masyarakat.

(4) Betapa aku bangga dan bersyukur ... Aku harus teguh tidak boleh runtuh ... Karena aku tahu, aku tak pernah sendiri ....

Pada analisis tingkat tata bahasa, tata bahasa pada teks iklan ini ditampilkan dalam bentuk peristiwa. Bentuk peristiwa hanya memasukkan satu partisipan saja dalam kalimat, baik subjek maupun objeknya saja. Iklan ini didominasi oleh pelaku (subjek) tanpa melibatkan partisipan lain (tanpa objek). Pelaku diwakili dengan pronomina aku yang merupakan pegawai pajak dalam iklan ini. Kata aku yang banyak bermunculan, berusaha menyampaikan pesan bahwa menjadi seorang pegawai pajak itu tidaklah mudah. Kata aku dalam banyak kalimat pada teks iklan ini digunakan untuk bercerita. Pemilihan kata aku daripada saya mungkin dimaksudkan untuk memperdekat jarak antara masyarakat dengan pegawai pajak yang belum sepenuhnya diterima di tengah-tengah masyarakat karena banyak dicurigai menyelewengkan pajak untuk memperkaya diri sendiri. Tentu, jika kata saya yang dipilih oleh pembuat teks, akan semakin memperlebar jarak antara pegawai pajak dengan masyarakat.

\section{Iklan III}

(5) hari gini gak bayar pajak penghasilan, apa kata dunia?

Pada iklan ini, penulis akan memfokuskan analisis pada slogan yang menjadi penekanan. Slogan yang menjadi penekanan yaitu apa kata dunia?. Slogan ini diletakkan di akhir teks setelah menjelaskan kewajiban setiap individu yang telah memiliki penghasilan untuk membayar pajak penghasilan dan menjelaskan pula pemanfaatan pajak tersebut. Slogan tersebut pada awalnya dipopulerkan oleh Deddy Mizwar dalam film yang dibintanginya 
yang berjudul Naga Bonar. Saat ini, iklan pajak ini berusaha untuk kembali mempopulerkan slogan tersebut.

Slogan ini tidak akan memiliki makna sesuai dengan pembuat teks inginkan tanpa adanya intonasi dari partisipan yang mengucapkannya. Intonasi tertentu yang menyertai slogan tersebut bermaksud menyindir individu, kelompok atau institusi tertentu yang tidak taat membayar pajak. Pembuat teks dalam iklan tersebut memberikan citra negatif kepada individu, kelompok atau institusi yang tidak membayarkan pajak penghasilannya, apapun itu alasannya. Citra negatif tersebut membentuk realitas dalam masyarakat bahwa tidak membayar pajak adalah sesuatu yang tidak dibenarkan dan menyalahi ketentuan yang berlaku.

(6) Papahku beli motor baru donk. Bapakku mobilnya yang baru. Bapakku punya jalan dan jembatan. Haah? Ga mungkin! Bapakku kan bayar pajak penghasilan ....

Pada tingkat tata bahasa, teks iklan ini ditampilkan dalam bentuk peristiwa. Di sini, unsur subjek hampir ada di setiap kalimat dalam teks iklan tersebut. Unsur subjek diwakili oleh kata papahku dan bapakku. Sosok seorang bapak menjadi sosok yang ingin ditampilkan oleh pembuat teks karena pria/bapaklah yang umumnya menanggung biaya pajak karena perannya sebagai seorang kepala keluarga. Dengan kata lain, iklan tersebut ditujukan untuk menyadarkan dan mendorong pria/bapak untuk membayar pajak.

\section{Representasi dalam Kombinasi Anak Kalimat}

Pada bagian ini, penulis akan menganalisis koherensi antar anak kalimat yang dihasilkan dalam beberapa bentuk hubungan. Bentuk-bentuk hubungan yang dapat ditemukan dalam teks iklan ini ada dua, yaitu elaborasi dan ekstensi. Elaborasi adalah hubungan di mana anak kalimat yang satu menjelaskan dan memperinci anak kalimat yang lain. Elaborasi ditandai dengan penggunaan konjungsi, seperti yang, lalu dan selanjutnya. Selain penggunaan bentuk hubungan elaborasi, terdapat bentuk hubungan ekstensi. Ekstensi adalah hubungan di mana anak kalimat yang satu merupakan penambahan atau perpanjangan dari anak kalimat yang lain. Ekstensi ditandai dengan penggunaan konjungsi dan, tetapi atau meskipun. Berikut ini akan dianalisis hubungan antar anak kalimat:

(7) Siapa yang tidak bahagia ... siapa yang tidak terharu ... siapa yang tidak tersentuh ....

Dalam teks iklan ini, terdapat kalimat yang masing-masing anak kalimatnya menggunakan konjungsi yang. Penggunaan konjungsi yang pada ketiga kalimat tersebut berfungsi untuk memperinci kata tanya siapa yang umumnya digunakan untuk bertanya. Pada iklan ini, kalimat tersebut mungkin tidak ditujukan untuk bertanya namun untuk menekankan bahwa tidak ada orang yang tidak bahagia, terharu dan tersentuh ketika melihat banyak orang tertolong dan termudahkan urusannya karena pajak.

(8) ... buku-buku gratis dan belajar ... berbagai layanan kesehatan dan obat- obatan ... dan ... bayi lahir sehat dan tumbuh cerdas ....

Penggunaan konjungsi dan sama jumlahnya dengan penggunaan konjungsi yang dalam teks iklan ini. Fungsi konjungsi dan di sini adalah menambahkan manfaat dari pajak untuk masyarakat. Pembuat teks ingin menekankan bahwa pajak memberikan manfaat yang begitu banyak seperti pada sektor pendidikan dan kesehatan yang menjadi prioritas utama dalam membangun bangsa. 


\section{Iklan II}

(9) ... selalu ada tangan maha kokoh yang siap membimbingku demi mewujudkan citacita bersama, bangsa yang sejahtera.

Penggunaan konjungsi yang dalam kalimat tersebut berfungsi untuk memperjelas untuk apa frasa metaforis tangan maha kokoh dan kata bangsa ditampilkan. Frasa metaforis tersebut mengacu kepada sang khalik (pencipta) yang maha kuasa yang diyakini akan membimbingnya (pegawai pajak) dalam menjalankan tugas mulianya yaitu mewujudkan bangsa yang sejahtera. Sedangkan kata bangsa disandingkan dengan kata sejahtera untuk memperjelas tujuan program pajak dalam iklan ini.

(10) Betapa aku bangga dan bersyukur dapat mengemban tugas mulia ini ... berbagai rintangan dan tantangan membayangi setiap langkahku ....

Teks iklan ini juga menggunakan bentuk hubungan ekstensi. Dalam teks iklan ini, penggunaan bentuk hubungan ekstensi terdapat di dua kalimat pertama iklan ini Penggunaan konjungsi dan pada kalimat pertama digunakan untuk menggabungkan dua kata kerja, yaitu bangga dan bersyukur. Dua kata tersebut memiliki citra positif yang dibuat oleh pembuat teks. Sedangkan konjungsi dan yang kedua, digunakan untuk menggabungkan dua kata benda yang bercitra negatif dan positif, yaitu rintangan dan tantangan.

Pembuat teks iklan ini sepertinya ingin menekankan bahwa tugas seorang pegawai pajak merupakan tugas yang membanggakan dan patut untuk disyukuri. Pada hakikatnya, apa pun pekerjaan yang kita jalani, sudah sepatutnya rasa bangga dan syukur itu ada, begitu pula pekerjaan sebagai pegawai pajak dalam iklan ini. Permasalahan mulai dimunculkan oleh pembuat teks pada bagian tengah teks yang salah satunya menyatakan bahwa berbagai rintangan dan tantangan membayangi setiap langkahku. Pemberian informasi mengenai permasalahan ini, mengimplisitkan bahwa tugas mulia ini memiliki banyak resiko dimanapun orang tersebut berada. Sejatinya, rintangan dan hambatan merupakan hal yang pasti ada dalam kehidupan dan tidak terbatas pada dunia kerja. Rintangan dan hambatan pun bersifat relatif, artinya tingkat kesulitan atau cobaan untuk masing-masing individu berbeda, tergantung kemampuan dan bagaimana individu menyikapi hal tersebut, serta lain sebagainya.

\section{Iklan III}

(11)... bapakku mobilnya yang baru ....

Sejenis dengan dua iklan pajak sebelumnya, iklan III ini memiliki dua jenis hubungan,

yaitu elaborasi dan ekstensi. Hubungan ini terdapat dalam kalimat bapakku mobilnya yang baru. Konjungsi yang digunakan untuk menjelaskan atau memperinci kata mobil. Sedangkan hubungan ekstensi, terdapat pada kalimat bapakku punya jalan dan jembatan. Dalam kalimat ini, terdapat penambahan kata jembatan dengan kata jalan.

\section{Representasi dalam Rangkaian Antarkalimat}

Pada bagian ini, yang menjadi fokus yaitu bagaimana kalimat-kalimat atau komentarkomentar disusun atau dirangkai dalam suatu teks dan bagaimana presentasi partisipan yang terlibat dalam rangkaian antar kalimat tersebut. Partisipan ditampilkan memberi reaksi terhadap pendapat partisipan lain.

\section{Iklan I}

(12)... makasih pajak.

Dalam teks ini, Deddy Mizwar sebagai aktor atau pelaku yang memberikan pendapatnya mengenai manfaat pajak dari bagian awal iklan hingga akhir. Setelah ia selesai memberikan 
penjelasan tersebut, pada bagian akhir iklan ini, terdapat partisipan lain yang memberikan komentar sebagai penutup. Mereka mengucapkan makasih pajak. Partisipan tersebut mengucapkan terima kasih kepada pajak seolah-olah hanya pajaklah yang berkontribusi terhadap diri mereka. Pajak hakikatnya dibayarkan oleh warga Indonesia karena adanya peraturan dari pemerintah. Pemerintah memiliki kuasa untuk menyuruh warganya berpartisipasi membayar pajak. Jadi pajak adalah sumber pendapatan negara yang berasal dari rakyat itu sendiri.

Menurut hemat penulis, pembuat teks seyogyanya mengapresiasi ketaatan dan kesediaan warga negara yang membayar pajak demi kemaslahatan rakyat banyak. Jika demikian, maka secara emosional, pembayar pajak merasa dilibatkan dan merasa diakui keberadaanya sehingga pembayar pajak tersebut dengan senang hati atau mungkin tanpa paksaan akan membayar pajak.

\section{Iklan II}

(13) Betapa aku bangga dan bersyukur dapat mengemban tugas mulia ini ...

Pada iklan ini, hanya terdapat satu partisipan dominan yang mana ia bercerita mengenai pekerjaannya sebagai seorang pegawai pajak. Dengan ditonjolkannya partisipan yang berprofesi sebagai pegawai pajak tersebut, dapat ditarik kesimpulan bahwa pembuat teks merupakan pihak yang tidak netral, melainkan memihak atau mendukung pegawai pajak tersebut.

\section{Iklan III}

(14) Papahku beli motor baru donk. Bapakku mobilnya yang baru. Bapakku punya jalan dan jembatan. Haah? Ga mungkin! Bapakku kan bayar pajak penghasilan ...

Pada iklan ini, partisipannya adalah tiga anak kecil dan seorang bapak. Ketiga anak tersebut ditampilkan saling memberikan reaksi terhadap suatu pendapat dengan pendapat lainnya. Pendapat anak yang ketiga tersebut lebih banyak diperlihatkan oleh pembuat teks dibandingkan pendapat dua anak sebelumnya. Pendapat anak yang ketiga tersebut menyatakan bahwa bapaknya memiliki jalan dan jembatan karena telah membayar pajak. Setelah itu, pendapat anak ketiga tersebut didukung oleh pendapat sang bapak yang menekankan pentingnya pajak hingga akhir iklan. Gambaran tersebut menjelaskan bahwa pembuat teks merupakan pihak yang mendukung atau memihak kepada institusi pajak.

\section{Relasi \& Identitas}

Analisis relasi berhubungan pada pembahasan hubungan antara para partisipan dalam suatu teks. Menurut Fairclough, terdapat tiga kategori partisipan utama dalam teks; wartawan (pembuat teks), khalayak media dan partisipan publik. 


\section{Iklan I}

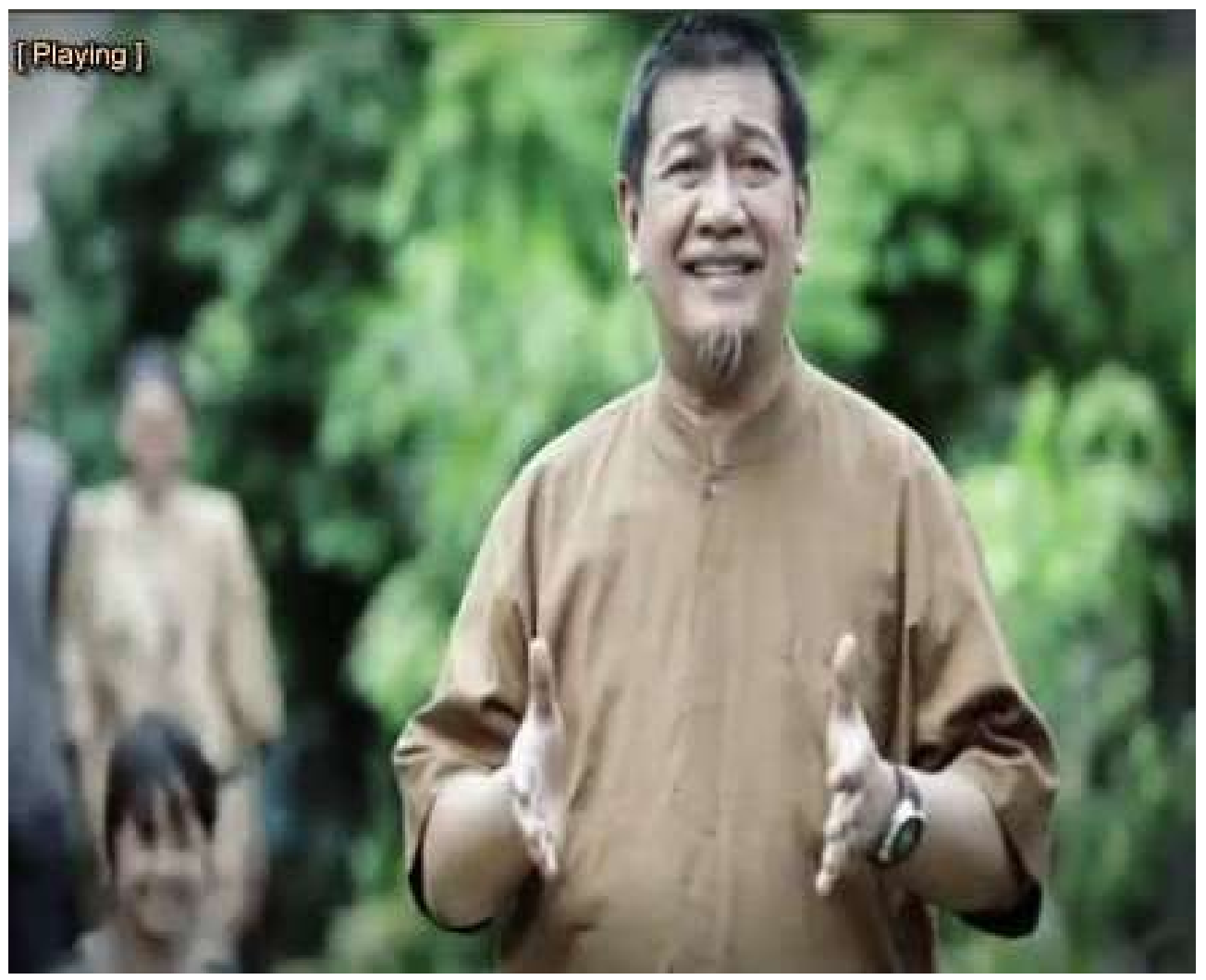

Gambar 1. Sosok Deddy Mizwar dalam iklan pajak

Pada iklan ini, dapat dilihat partisipannya yaitu pembuat teks, khalayak media dan partisipan publik (artis yang menjadi aktor dalam iklan ini, yaitu Deddy Mizwar). Pembuat teks iklan merupakan perwakilan dari institusi pajak karena ia mendapatkan tugas untuk membuat iklan pajak, lalu menyebarluaskannya kepada khalayak melalui media elektronik, dalam hal ini televisi (TV). Karena iklan di TV tidak hanya terbatas pada teks, pembuat iklan harus menarik simpati khalayak dengan menggunakan aspek audiovisual. Pada aspek visual, pembuat teks menggunakan jasa artis (publik figur) Deddy Mizwar untuk menyampaikan pesan. Pemilihan artis untuk menyampaikan pesan tersebutpun tidak sembarangan. Kriteriakriteria tertentu menjadi pertimbangan. Sosok Deddy Mizwar yang dianggap dewasa dan bijak, dapat menyampaikan pesan iklan ini dengan baik dan diharapkan khalayak media dapat mencontoh artis tersebut dan juga menerima pesan yang coba untuk disampaikan. Dalam analisis identitas, pembuat teks iklan ini bukanlah pihak yang netral namun memihak pada pemesan iklan yang tidak lain adalah institusi pajak. 


\section{Iklan II}

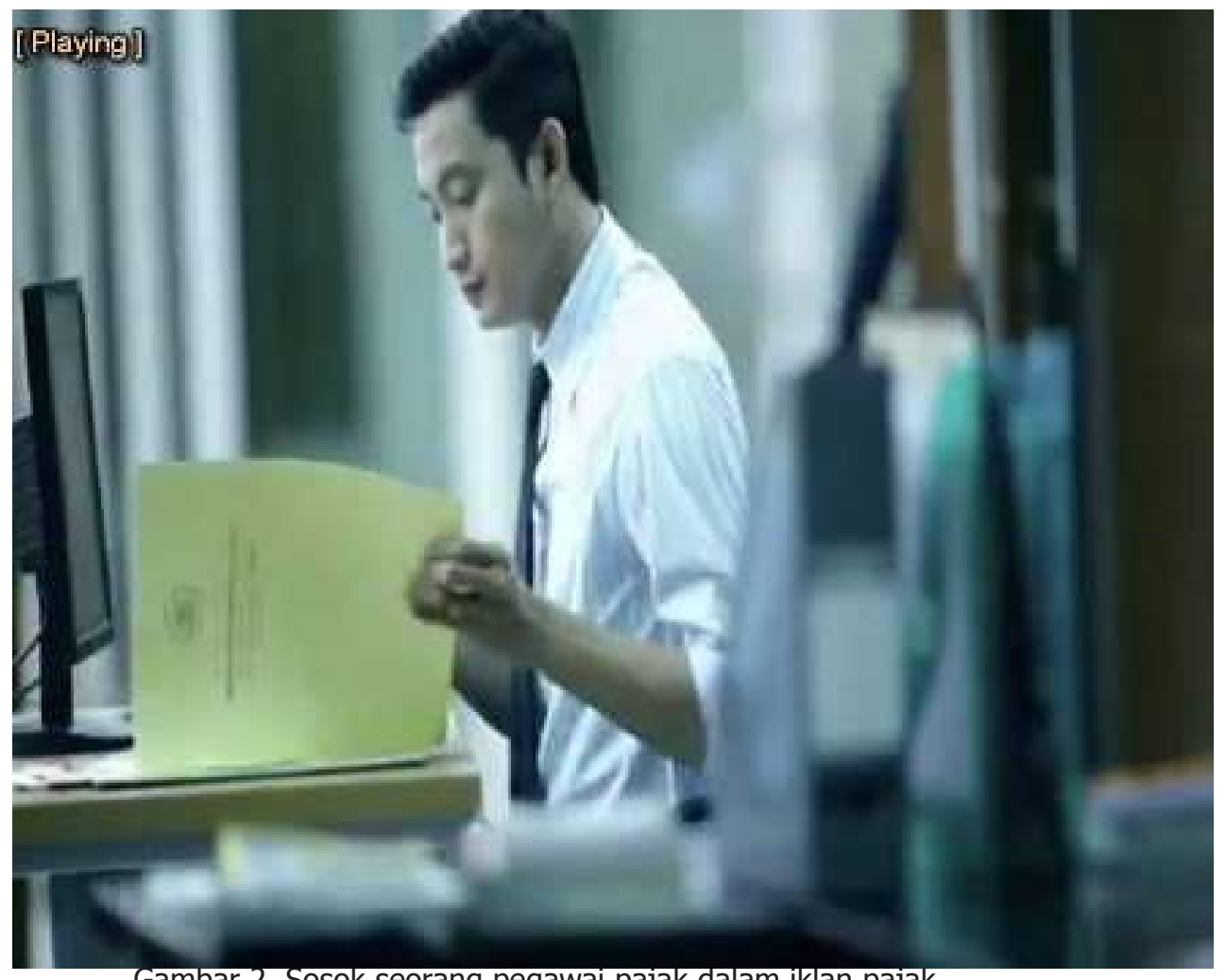

Gambar 2. Sosok seorang pegawai pajak dalam iklan pajak

Pada iklan ini, dapat dilihat partisipannya yaitu; pembuat teks, khalayak media dan partisipan publik. Partisipan publik dalam iklan ini berperan sebagai pegawai pajak yang berusaha menjalankan tugasnya dengan sebaik-baiknya. Pegawai pajak tersebut mewakili pegawai-pegawai pajak lainnya di institusi pajak. Pembuat teks iklan juga merupakan perwakilan dari institusi pajak karena ia mendapatkan tugas untuk membuat iklan pajak oleh institusi tersebut, lalu menyebarluaskannya kepada khalayak melalui media elektronik, dalam hal ini TV. Karena iklan di TV tidak hanya terbatas pada teks, pembuat iklan harus menarik simpati khalayak dengan menggunakan aspek audiovisual. Dalam analisis identitas, pembuat teks iklan ini bukanlah pihak yang netral namun memihak pada pemesan iklan yang tidak lain adalah institusi pajak.

\section{Iklan III}
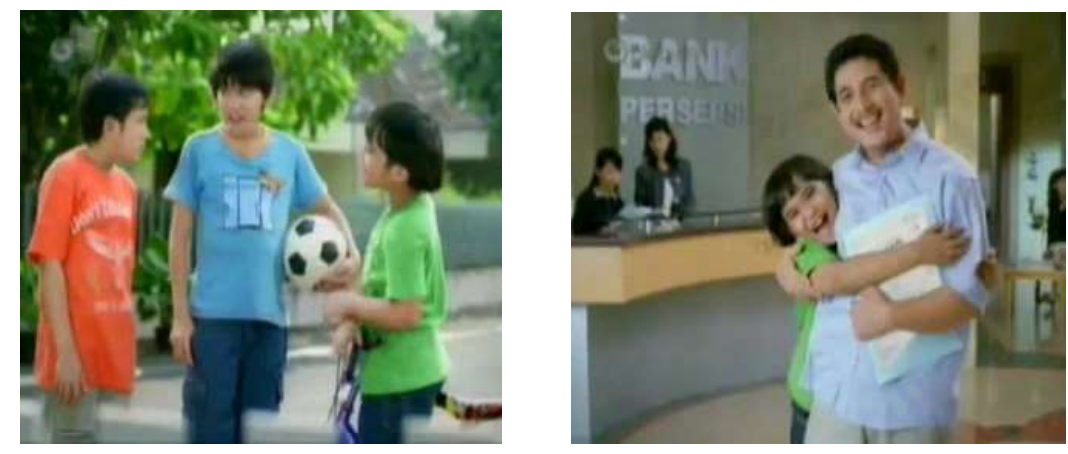

Gambar 3 \& 4. Tiga anak kecil dan seorang pria yang berperan sebagai bapak anak yang ketiga. 
Pada iklan ini ini, dapat dilihat partisipannya yaitu pembuat teks, khalayak media dan partisipan publik. Partisipan publik dalam iklan ini bukanlah artis yang sudah terkenal seperti pada iklan I. Mereka adalah tiga anak kecil dan seorang pria yang berperan sebagai bapak dari anak yang ketiga. Pembuat teks iklan merupakan perwakilan dari institusi pajak karena ia mendapatkan tugas untuk membuat iklan pajak, lalu menyebarluaskannya kepada khalayak melalui media elektronik, dalam hal ini TV. Karena iklan di TV tidak hanya terbatas pada teks, pembuat iklan harus menarik simpati khalayak dengan menggunakan aspek audiovisual.

Pada aspek visual, pembuat teks menggunakan jasa artis (publik figur) tiga anak kecil dan seorang pria yang berperan sebagai bapak anak yang ketiga untuk menyampaikan pesan. Meski bukan artis yang sudah dikenal, peran mereka berempat diharapkan menjadi contoh bagi khalayak media agar taat membayar pajak demi kesejahteraan bangsa. Dalam analisis identitas, pembuat teks iklan ini bukanlah pihak yang netral namun memihak pada pemesan iklan yang tidak lain adalah institusi pajak.

\section{Analisis pada Dimensi Praktik Wacana}

Pada bagian ini, analisis difokuskan pada bagaimana produksi dan konsumsi teks. Menurut Fairclough, ada dua sisi dari praktik ini, yaitu produksi teks (di pihak media) dan konsumsi teks (di pihak khalayak). Pembuat teks dengan berbagai nilai ideologis yang mendasarinya, menghasilkan sebuah teks. Proses konsumsi dilakukan pembaca secara personal ketika mengkonsumsi sebuah teks.

\section{Iklan I}

(15) Siapa yang tidak bahagia, melihat jutaan anak Indonesia dapat terus sekolah. Semua memperoleh pinjaman buku-buku gratis dan belajar dengan gembira tanpa harus dibebani beratnya uang SPP. Siapa yang tidak terharu melihat makin banyak keluarga bisa memperoleh berbagai layanan kesehatan dan obatobatan tanpa harus memikirkan besarnya biaya ....

Pada iklan ini, produksi teks dibuat dengan merujuk pada realitas, di mana anakanak dapat bersekolah dengan gratis, warga kurang mampu dapat menikmati pelayanan kesehatan yang murah, bahkan gratis, namun tetap prima. Realitas ini dituangkan ke dalam teks oleh pembuat teks, lalu disebarluaskan kepada khalayak melalui TV. TV merupakan media penyampaian pesan yang efektif karena pesan yang ingin disampaikan, ditayangkan berulangkali sehingga khalayak secara sadar atau tidak, menyimpan pesan tersebut di benak mereka.

Pada konsumsi teks, khalayak melakukan proses konsumsi teks secara personal berdasarkan interpretasi, konteks dan latar belakang pengetahuan tertentu. Suatu individu dengan individu yang lain menginterpretasi iklan ini secara berbeda-beda. Hal tersebut mungkin disebabkan karena latar belakang pengetahuan dan pendidikan mereka yang berbeda pula.

\section{Iklan II}

(16) ... Berbagai rintangan dan tantangan membayangi setiap langkahku ... Aku harus teguh tidak boleh runtuh. Terus melangkah tak akan menyerah ... demi mewujudkan cita-cita bersama, bangsa yang sejahtera.

Pada iklan ini, tahap produksi teks dibuat oleh pembuat teks untuk membentuk citra positif pegawai pajak. Sebelum kehadiran iklan ini, institusi pajak sedang dilanda masalah yang melibatkan oknum pegawai pajak. Oknum pegawai pajak tersebut tersandung masalah 
korupsi dan hal tersebut mengurangi kepercayaan masyarakat akan institusi ini. Oleh karena itu, iklan ini dihadirkan untuk mengumpulkan kembali kepercayaan masyarakat dan agar masyarakat tidak menilai semua pegawai di institusi ini sama seperti satu oknum tersebut.

Pada bagian konsumsi teks, khalayak atau masyarakat tidak dengan mudah mempercayai institusi ini karena kehadiran masalah tersebut. Banyak dari mereka yang beranggapan bahwa kasus oknum pegawai pajak itu bagaikan puncak gunung es yang muncul di permukaan laut. Pengetahuan mereka sebelumnya membentuk realitas bahwa institusi yang mengurusi keuangan seperti pajak, sangat rentan terhadap masalah korupsi.

\section{Iklan III}

(17) ... Pajak juga untuk membiayai bantuan operasional sekolah, imunisasi, subsidi listrik, dll. Di seluruh Indonesia ....

Pada iklan ini, analisis produksi teks tidak jauh berbeda dengan analisis pada iklan I, yaitu merujuk pada realitas yang ada. Namun, iklan ini mengkhususkan hanya pada pajak penghasilan (Pph). Pembuat teks memotret realitas yang ada seperti adanya subsidi listrik, bantuan operasional, dll., lalu menuliskannya ke dalam teks iklan ini. Teks tersebut kemudian disebarluaskan melalui media TV agar masyarakat mengetahui pentingnya membayar pajak.

Pada bagian konsumsi teks, secara umum, masyarakat memahami pesan yang disampaikan oleh iklan ini. Masyarakat yang membayar pajak tentu berharap uang yang mereka berikan tersebut bermanfaat dan tidak disalahgunakan.

\section{Analisis pada Dimensi Praktik Sosial-budaya}

Analisis pada praktik ini didasarkan pada asumsi bahwa konteks sosial yang ada di luar media, mempengaruhi wacana yang muncul. Meskipun praktik ini tidak berhubungan langsung dengan produksi teks, namun menentukan bagaimana teks diproduksi dan dipahami. Praktik ini menggambarkan bagaimana kekuatan-kekuatan yang ada dalam masyarakat memaknai dan menyebarkan ideologi yang dominan kepada masyarakat.

\section{Iklan I}

Teks iklan ini dipengaruhi oleh tiga level; situasional, institusional dan sosial. Pada level situasional, teks iklan ini dipahami sebagai suatu tindakan. Seperti halnya penjelasan pada bagian praktik wacana di atas, teks ini hadir dengan melihat realitas yang ada, yaitu anak-anak dapat bersekolah gratis dan masyarakat kurang mampu dapat menikmati pelayanan kesehatan dengan biaya yang terjangkau (lihat poin (2) dan (15)). Pada level institusional, teks mendapatkan pengaruh dari institusi atau organisasi. Teks iklan pajak ini, tentu mendapatkan pengaruh yang signifikan dari institusi pajak karena institusi tersebutlah yang menginginkan adanya iklan ini. Sedangkan pada aspek sosial, teks yang muncul pada iklan ditentukan oleh perubahan dalam masyarakat. Iklan ini hadir untuk menghimbau masyarakat agar taat membayar pajak. Himbauan tersebut dapat ditafsirkan berbeda. Iklan ini dapat ditafsirkan sebagai pengingat atau sebagai alat pendorong dan penggugah masyarakat untuk membayar pajak.

\section{Iklan II}

Pada iklan ini, teks iklan dihasilkan dalam situasi dan kondisi yang tepat. Situasi kemunculan iklan ini adalah ketika terdapat kasus korupsi yang mencoreng wajah institusi pajak yang disebabkan karena oknum pegawai pajak yang serakah. Iklan ini berupaya membersihkan citra negatif yang sudah melekat dan mencoba membangun kembali kepercayaan masyarakat yang telah pudar akan institusi ini. 
Pada level institusional, penjelasan pada level ini sejenis dengan iklan I, yaitu teks iklan ini hadir karena pengaruh yang signifikan dari institusi pajak. Sedangkan pada aspek sosial, perubahan sikap masyarakat terhadap pajak, yang mungkin sebelumnya mendukung langkah pajak, saat ini mulai banyak yang bersikap skeptis dan bahkan apatis. Oleh karena alasan tersebut, iklan ini hadir.

\section{Iklan III}

Pada teks iklan ini, iklan ini hadir dalam situasi tertentu di mana pemerintah sedang memaksimalkan pendapatan negara dari sektor pajak. Institusi pajak berupaya mengajak masyarakat untuk taat membayar pajak sehingga program-program pemerintah dapat terlaksana. Pada level institusional, penjelasan pada level ini sejenis dengan iklan I dan II, yaitu teks iklan ini hadir karena pengaruh yang signifikan dari institusi pajak kepada pembuat teks. Sedangkan pada aspek sosial, iklan ini hadir ketika suasana politik di Indonesia sedang stabil dan tidak ada masalah yang berarti.

\section{SIMPULAN}

Berdasarkan hasil analisis tiga dimensi Fairclough, dapat ditarik kesimpulan bahwa pada dimensi teks, analisis representasi dalam anak kalimat pada ketiga teks iklan pajak tersebut memberikan dua gambaran. Gambaran pertama pada kata, kosakata, frasa atau slogan tertentu yang menjadi penekanan dalam teks iklan ini didominasi untuk tujuan pencitraan terhadap institusi dan juga pencitraan negatif terhadap individu, kelompok atau institusi yang tidak taat membayar pajak, sedangkan gambaran kedua pada tata bahasa, teks ketiga iklan ini ditampilkan dalam bentuk mental dan peristiwa di mana pada iklan pertama, unsur subjek tidak dimunculkan secara spesifik, sedangkan iklan kedua dan ketiga, hanya unsur subjek yang disertakan tanpa melibatkan unsur objek.

Pada bagian representasi dalam rangkaian antarkalimat, kalimat-kalimat atau komentar-komentar disusun atau dirangkai dalam suatu teks dan bagaimana presentasi partisipan yang terlibat dalam rangkaian antar kalimat tersebut. Pembuat teks (biro iklan) merangkai teks sedemikian rupa sehingga terlihat jelas bahwa ia merupakan pihak yang tidak netral, namun memihak kepada institusi pajak (Dirjen pajak). Pada bagian relasi \& identitas, hubungan yang terdapat antara pembuat teks, khalayak media dan partisipan publik (dalam hal ini artis) adalah hubungan saling mempengaruhi. Pembuat teks mendapatkan pengaruh yang signifikan dari institusi pajak dalam pembuatan iklan ini dan menggunakan jasa artis untuk mempengaruhi dan mengajak khalayak agar taat membayar pajak.

Pada dimensi praktik wacana, terdapat penjelasan bagaimana teks diproduksi, disebarluaskan dan dikonsumsi. Teks pada iklan-iklan ini disebarluaskan lewat media TV. Pihak pemroduksi adalah biro iklan yang mendapatkan pengaruh dari institusi pajak sebagai pemesan iklan. Pesan tersebut lalu dikonsumsi oleh khalayak dengan tujuan untuk pencitraan dan mengangkat realitas sebagai upaya menarik simpati khalayak. Sedangkan pada dimensi sosial- budaya, Analisis pada praktik ini didasarkan pada asumsi bahwa konteks sosial, seperti sikap masyarakat \& suasana politik dapat mempengaruhi wacana yang muncul. Wacana iklan ini ingin membentuk realitas bahwa jika orang taat membayar pajak, maka sektor pendidikan dan kesehatan dapat memberikan pelayanan prima kepada masyarakat sebagai timbal balik dari pajak itu sendiri.

Namun realitas yang ada, masih banyak masyarakat kurang mampu sulit untuk mendapatkan pelayanan kesehatan yang maksimal seperti yang diiklankan. Diharapkan, seiring meningkatnya pemasukan negara melalui pajak, realitas yang ingin dibentuk dapat menyentuh semua lapisan masyarakat, terutama masyarakat yang tidak mampu. Selain itu, pembuat teks dalam wacana iklan ini memberikan citra negatif kepada individu, kelompok 
atau institusi yang tidak membayarkan pajak penghasilannya, apapun itu alasannya. Citra negatif ini membentuk realitas dalam masyarakat bahwa tidak membayar pajak adalah sesuatu yang tidak dibenarkan dan menyalahi ketentuan yang berlaku. Jika realitas ini sudah diterima, maka ketaatan masyarakat untuk membayar pajak dapat terwujud.

\section{SARAN}

Pada bagian ini, penulis memberikan saran untuk perkembangan studi kebahasaan, terutama pada kajian yang menggunakan Analisis Wacana Kritis (AWK) sebagai parameternya. Menurut pengamatan penulis, pada umumnya, AWK digunakan sebagai parameter untuk membedah wacana pada media massa surat kabar. Penulis belum banyak menemukan penggunaan parameter tersebut untuk membedah wacana lain seperti yang penulis lakukan, yaitu membedah wacana iklan. Diharapkan dengan beraneka ragam penggunaan parameter ini untuk mengkaji berbagai macam wacana yang ada, penemuan-penemuan baru dapat ditemukan untuk memperkaya khazanah kebahasaan.

Selain itu, hasil analisis yang sudah dipaparkan pada bagian simpulan dapat dijadikan sebagai masukan untuk para pembuat teks iklan dalam membuat iklan-iklan, terutama iklan pajak agar dapat lebih baik kedepannya. Menampilkan dan mengapresiasi masyarakat yang telah berpartisipasi dengan cara membayar pajak merupakan hal yang perlu dilakukan. Hal ini dimaksudkan agar masyarakat tersebut merasa dihargai dan diakui keberadaannya. Di sisi lain, pencitraan negatif terhadap individu, kelompok dan institusi tertentu yang belum bisa atau tidak membayarkan pajak dengan alasan apapun, dapat menimbulkan penafsiran yang berbeda-beda di dalam masyarakat. Pencitraan seperti itu sebaiknya dihindari karena dapat menimbulkan sikap apatis masyarakat tertentu terhadap institusi pajak. Menurut hemat penulis, pembuat teks sebaiknya terus mempersuasi masyarakat untuk membayar pajak dengan mengangkat realitas yang ada. Realitas yang di maksud adalah manfaatmanfaat pajak yang sudah dirasakan langsung oleh masyarakat dalam bentuk yang nyata, seperti adanya pendidikan gratis, pelayanan kesehatan untuk masyarakat kurang mampu, subsidi listrik, dll. Disamping mengangkat realitas yang sudah ada, diharapkan pemerintah menciptakan realitas baru berupa manfaat-manfaat pajak yang baru dan dirasakan oleh masyarakat umum, terutama masyarakat yang kurang mampu agar ada stimulasi tertentu untuk meningkatkan pajak demi kesejahteraan bangsa. 


\section{Daftar Pustaka}

Eriyanto. 2001. Analisis Wacana: Pengantar Teks Media. Yogyakarta: LkiS.

Fairclough, Norman. 1995. Critical Discourse Analysis: The Critical Study of Language. USA: Longman Group Ltd.

Jan Blommaert and Chris Bulcaen, "Critical Discourse Analysis," Annual Review of Anthropology (Vol. 29, 2000), pp. 447-466.

Jann Scheuer, "Habitus as the Principle for Social Practice: A Proposal for Critical Discourse Analysis," Language and Society (Vol. 32, No. 2, April 2003), pp. 143175.

Nelson Phillips, Thomas B. Lawrence and Cyntia Hardy, "Discourse and Institutions," The Academy of Management Review (Vol. 29, No. 4, October 2004), pp. 635652.

Pegeen Reichert Powell, "CDA and Compositions studies: A Study of Presidental Discourse and Campus Discord," College Composition and Communication (Vol. 55, No. 3, February 2004), pp. 439-469.

Rebecca Rogers, Elizabeth Malancharuvil-Berkes, Melissa Mosley, Diane Hui and Glynis O'Garro Joseph, "Critical Discourse Analysis in Education: A Review of the Literature." Review of Educational Research (Vol. 75, No. 3, Autumn 2005), pp. 365-416.

Renkema, Jan. 2004. Introduction to Discourse Studies. Amsterdam/Philadelphia: John Benjamins Publishing Company. 